\title{
Exploring Antecedents of Turnover Intention Among Generation Y Employees in Construction Industry
}

Neeta Syairul Amelia Binti Safian, Zaiton Hassan, Mark Kasa, Nur Fatihah Abdullah Bandar, Nik Norsyamimi Md Nor

To Link this Article: http://dx.doi.org/10.6007/IJARBSS/v11-i2/8621

DOI:10.6007/IJARBSS/v11-i2/8621

Received: 11 December 2020, Revised: 04 January 2021, Accepted: 23 January 2021

Published Online: 06 February 2021

In-Text Citation: (Safian et al., 2021)

To Cite this Article: Safian, N. S. A. B., Hassan, Z., Kasa, M., Abdullah Bandar, N. F., \& Nor, N. N. M. (2021). Exploring Antecedents of Turnover Intention Among Generation Y Employees in Construction Industry. International Journal of Academic Research in Business and Social Sciences, 11(2), 117-130.

\section{Copyright: (c) 2021 The Author(s)}

Published by Human Resource Management Academic Research Society (www.hrmars.com)

This article is published under the Creative Commons Attribution (CC BY 4.0) license. Anyone may reproduce, distribute, translate and create derivative works of this article (for both commercial and non-commercial purposes), subject to full attribution to the original publication and authors. The full terms of this license may be seen

at: http://creativecommons.org/licences/by/4.0/legalcode

$$
\text { Vol. 11, No. 2, 2021, Pg. } 117 \text { - } 130
$$

Full Terms \& Conditions of access and use can be found at http://hrmars.com/index.php/pages/detail/publication-ethics 




\title{
Exploring Antecedents of Turnover Intention Among Generation Y Employees in Construction Industry
}

Neeta Syairul Amelia Binti Safian', Zaiton Hassan ${ }^{1}$, Mark $\mathrm{Kasa}^{2}$, Nur Fatihah Abdullah Bandar ${ }^{1}$, Nik Norsyamimi Md Nor ${ }^{1}$ ${ }^{1}$ Faculty of Cognitive Sciences and Human Development, Universiti Malaysia Sarawak, 93400 Kota Samarahan, Sarawak, Malaysia, ${ }^{2}$ Faculty of Hospitality and Tourism Management, UCSI University Sarawak Campus, Lot 2864, Block 7, Muara Tebas Land District, Isthmus, Tanjong

Seberang Pending Point, Sejingkat, 93450 Kuching, Sarawak, Malaysia

Email: hzaiton@unimas.my

\begin{abstract}
Current reports claim that the constantly switching job became a norm among the Generation $Y$ workforce in Malaysia with the reason being dissatisfied with the organization's working system, pay and fringe benefits. This study aims to explore the antecedent leading to the Generation Y employees' turnover intention. Five (5) Generation Y informants in construction industry were interviewed. Findings showed that generation $Y$ employees prefer to stay at the current organization at least within five years. Antecedents of turnover intention identified are dissatisfaction towards the amount of wage received, a fringe benefits, access to better career opportunity or to change their career as well as family and/or personal reason. Retention factors identified include training and development, career development and good salary. Thus, to retain and motivate generation $Y$ employees, organizations should implement proper human resource development programs such as training and career development while paying comparable salary and benefits.
\end{abstract}

Keywords: Turnover Intention Antecedents, Generation Y, Malaysia.

\section{Introduction}

Turnover intention is a current issue confronted by organizations globally. Specifically, issues of turnover intention among individuals of Generation $Y$ is a present-day phenomenon (Sujansky \& Ferri-Reed, 2009; Yusoff et al., 2013). Currently, they are three generations dominating the workplace, they are those of the older generation known as Baby Boomers, those born around the early 1960s to late 1970s known as Generation X, and the Millennials or known as Generation Y. With Generation Y as the major occupancies of the workforce, Baby Boomers start moving towards retirement and Generation $\mathrm{X}$ being promoted to senior positions.

Studies reported that within Asia, Generation $Y$ employees have shorter job tenure (18 months on average) when compared to the two-generation preceding Generation $Y$ (up to 4 
years) (Queiri et al., 2015; Sheahan, 2008). With Generation Y occupying most of the modern workforce, human resource (HR) practitioners throughout Asia including Malaysia need to emphasize on turnover intention among employees of Generation Y.

While battling with the issue of talent shortages, Malaysia and its HR practitioners should not neglect the intensity of turnover intention among their Generation Y workforce (Downe et al., 2012). The Malaysian Statistic Research Department (2016) reported that by 2020, Generation $Y$ will occupy more than a quarter of the global workforce and more than three quarters by 2025. In Malaysia, more than half of the working population consist of Generation $\mathrm{Y}$ individuals. The issue of Generation $\mathrm{Y}$ being a major contributor of turnover among various industries has been highlighted in various newspapers and reports to indicate its intensity (PwC, 2012). With more than half of the Malaysia workforce constituting for Generation $Y$, the turnover issue faced by all industries should not be taken lightly.

In the Malaysian context, empirical studies need to be conducted to justify and identify the reasons contributing to Generation Y's turnover intention (James et al., 2008). Although many studies focused on turnover intention (Juhdi et al., 2013; Zulbahari \& Alias, 2014), few emphasize on Generation $Y$ as the subject. Past research within the Malaysian context considered extrinsic rewards as a factor that influences turnover intention (Choi et al., 2012; Queiri et al., 2015), while relatively few focuses on family-related factors (Choi, 2016; Samad, 2006) As Malaysia is a collectivist society (Hofstede et al., 2005), parents and extended families are important to an individual, thus family-related factors are worth studying. Therefore, this study focuses on the turnover intention among Generation $Y$ employees by exploring its factor related to work/extrinsic and family.

\section{Literature Review}

\section{Turnover Intention}

Turnover intention refers to the probability an employee voluntarily seeks to leave their current job (Schyns et al., 2007; Tett \& Meyer, 1993). According to Boles et al. (2007), the turnover intention is connected to turnover behaviour and it serves as an immediate indicator to actual turnover (Hom \& Griffeth, 1991). As such, turnover intention relates to one's behaviour, and employees leave an organization for a variety of reasons either related to work, the organization itself or because of personal or family reasons. Thus, organisations need to study and understand the causes of turnover intention. By understanding the causes, organisations will be able to strategize ways aimed at retaining talents.

\section{Antecedents of Turnover Intention}

One of the work-related antecedents or turnover intention is job satisfaction. According to Locke's (1976) fulfilment theory, job satisfaction arises when employees feel being valued at work. Job dissatisfaction arises when employees feels that their job or various aspect of the workplace is inconsistent with their perceived expectations. Furthermore, there is a relationship between work value and job satisfaction/dissatisfaction. For example, if an employee perceives their work value was not satisfied, it might lead to job dissatisfaction and vice versa. Various literature supported that the experience of job satisfaction can reduce turnover intention among employees. Employees experiencing a greater level of job satisfaction tend to develop a positive outlook towards their job and employees experiencing job dissatisfaction are more likely to develop a negative outlook with a strong intention to leave. Ahmad et al. (2012) identified a significant yet negatively related correlation between job satisfaction and turnover intention. A study by Mbah and Ikemefuna (2012) found that a 
higher level of job satisfaction among employees will result in lower levels of turnover intention. Besides that, Generation Y employees favour extrinsic rewards (Lee et al., 2012). Providing extrinsic rewards that fit and fulfil the needs of Generation $Y$ employees can cause a positive change in the perception of the employees towards their work, this phenomenon can be explained using the theory of values fulfilment. Thus, work values and extrinsic rewards tend to influence job satisfaction in which job satisfaction will lead to the occurrence of turnover intention among employees of Generation Y.

Furthermore, job stress is known as an antecedent of turnover intention. Frith et al. (2004) state that job stress is one of the factors leading to turnover intention, accompanied by job dissatisfaction and the lack of commitment towards one's organisation. Having employees who suffer from high levels of job stress can have negative consequences such as reduce in productivity, motivation, job skills and turnover intention reflected upon the employers. Generation $Y$ employees have different expectation from their organisation. The result of their expectation can influence the way they behave (Twenge \& Campbell, 2008). Thus, an unmet expectation can create intense stress at work which could contribute to a higher level of intention to quit (Ahmad et al., 2012).

\section{Characteristics of Generation Y Workforce}

Generation can be regarded as a collective of people being born and living at a parallel timeline and had experience similar important life events (Kupperschmidt, 2000). Generation Y are individuals born between 1977 until 1994 (Barron et al., 2007). However, there have been considerable arguments on the criteria to classify an individual as Generation Y. Several studies stated that individuals must be born around late 1977 to early 2002 to be classified as Generation Y (Congressional Research Service, 2008; Karefalk et al., 2007).

Generation $Y$ perceived work, working principle and working relationships differently when compared to individuals of the previous generation. Generation $Y$ likes to participate in work that is more challenging and adventurous which can build their skills and abilities (Kultalahti \& Viitala, 2015), they like immediate feedback are technologically savvy. According to Martin (2005), Generation Y craves for autonomy, dare to take risk, embrace challenges, fast learners and well educated.

According to Black (2010), Generation $\mathrm{Y}$ is known as the generation which requires the highest effort to maintain a good relationship and they tend to exhibit less loyalty to their employer. They will not hesitate to resign if an organisation is unable to deliver the work values they prefer, the reason so partly deriving from the impatience characteristics of most Millennial (Kim et al., 2009). In the workplace, Generation Y employees were often perceived as individuals who have an unreasonable expectation of getting promoted quickly (Karefalk et al., 2007).

The characteristics of Generation $Y$ differ from the previous two generations. During the time they are growing up, Generation $Y$ is exposed to drastic changes happening in the world such as unobstructed access to education, technological advancements, the modern society is getting wealthier, and globalization. These factors in certain ways influence the characteristics of Generation, making them different from those of the previous generation (Tapscott, 2009). In comparison to the prior two generations, Generation $Y$ exhibits characteristics such as independence, confidence, enthusiasm and ambitious. Generation $\mathrm{Y}$ is considered a generation with the privilege to gain access to educational opportunities. Most Generation $Y$ individuals proceed with a high-level education degree after leaving high school, they to go as far as obtaining a Doctorate (Meier \& Crocker, 2010). 
Generation $Y$ employee performs well when they are self-aware of the skills and abilities which they possess, accompanied with tasks that are challenging enough to motivate them to move forward (Martin \& Tulgan, 2006). Besides that, Generation Y prefers a career which allows to provide them with training and developmental opportunities and long-term job assurance. Generation Y embrace challenges and enjoy positive and caring work environment (Guillot-Soulez \& Soulez, 2014; Gursoy et al., 2008). Generation Y employees lack the loyalty that their predecessors have towards the organisation they are working for, they emphasize more on what the organisation can offer them such as autonomy, flexible working hours, and able to have fun at work (Loughlin \& Barling, 2001). Besides that, Generation Y employees prefer to work with people who have the same interest and goals, share the same values, and people who are committed to their work (Allen, 2004). When it comes to making decision making in an organization, Generation $Y$ employees dislike something bored, they want their organization to have them involved in the process decision making and appreciate that their ideas to be regarded as a something positive. However, in Malaysia, most of the organization still have most leaders from generation $X$ which make Generation $Y$ employees in the organization who are still new in the industry need to always follow through whatever decision from the leader and unable to voice up any opinion or view for the organization. This situation sometimes makes some of this Generation employee felt unappreciated and at the end leave the organization.

Generation $Y$ tends to emphasize more on their work by working for long hours and often neglecting the need to spend time with family, friends and pursuing self-interests (Susan, 2005). They are not afraid to take on more responsibilities or overload themselves with their task because for them this can prove their skills and talents. In Malaysia, this characteristic makes Generation $Y$ an essential workforce in the 21 st.

\section{Construction Industry in Malaysia}

Engineering and construction industry is the largest industry in the world (Shabanesfahani \& Tabrizi, 2012). In the construction industry in Malaysia, there is an urgency to provide their employees with training and development opportunities that fit the industry's needs (Kementerian Kerja Raya Malaysia, 2011).

Due to its nature, the construction industry is a knowledge-base and expertise and experience-oriented industry. Thus, it is not easy and costly to find and replace an employee from the industry. It will take time and cost for an organization to train new employees to prepare him or her with skills and expertise. Most of the challenges encountered by an organisation related to the retaining talents of the industry. The cost deriving from employees leaving their jobs in the construction industry can become substantially high. Within the construction industry, the lack of skilled labour will contribute towards the increase in the cost of construction and the decrease in the ability to innovate and the impact will further lead to the decrease in manpower productivity. The reason why the lack of skilled labour can lead to such intense outcome is mainly related to how the construction industry operates, and the high labour cost the industry is required to bear.

The construction industry is one of the industries that struggle when it comes to meeting constantly growing demand. The ADP Workforce Vitality Index 2017 stated that one of the factors that negatively affect construction companies is the high levels of turnover rate among the employees (Marc, 2018). Despite having a various generation of people working in the same organisation, most of the turnover derived from Generation Y employees (Zulbahari \& Alias, 2014). Before to the time before Generation $Y$ enter the workforce, this issue has never 
been so severe (Sujansky \& Ferri-Reed, 2009; Yusoff et al., 2013). Due to the work nature of the construction industry, which is stressful and unstable, high importance should be placed on the issue of turnover among construction personnel.

\section{Methods}

This study has been done qualitatively through face-to-face In-depth interview as the main research tool. The informants are selected by focusing on generation $Y$ respondents which are born between 1977 until 1994 deriving from the construction Sector in Miri Sarawak, Malaysia.. The interview took 30 minutes to 60 minutes for each informant.

\section{Results and Discussions}

\section{Interview}

The interview covered three research question which includes, Research Question 1 on an informant's envisioning in five years. Research Question 2 on the factors that influences the informants to leave the previous organization. Meanwhile, Research Question 3 to more investigate and identified why factors from section 2 directly influences them to leave the organization and to change their career perspectives.

The informants' age ranges from 28 to 34 years old which falls under the categorization of Generation Y. There are 3 informants were male and the remaining 2 were female. All the informants are those with a bachelor's degree and Diploma as their highest qualification. Informant's career is including HR Officer, Assistant Engineer, Site Coordinator, Manager Construction and Clerk of Work. 3 of informants married with a working spouse and other 2 informants still single.

Table 1

Informants demographic background

\begin{tabular}{ccccccc}
\hline Informant & Age & Gender & $\begin{array}{c}\text { Marital } \\
\text { Status }\end{array}$ & $\begin{array}{c}\text { No. of } \\
\text { Children }\end{array}$ & Qualification & Job Position \\
\hline Informant 1 & 34 & Male & Married & 2 & Bachelor's degree & $\begin{array}{c}\text { Manager } \\
\text { Construction }\end{array}$ \\
Informant 2 & 28 & Male & Single & 0 & Diploma & $\begin{array}{c}\text { Site } \\
\text { Coordinator }\end{array}$ \\
Informant 3 & 30 & Female & Single & 0 & Bachelor's degree & HR Officer \\
Informant 4 & 29 & Male & Married & 1 & Bachelor's degree & $\begin{array}{c}\text { Assistant } \\
\text { Engineer }\end{array}$ \\
Informant 5 & 28 & Female & Married & 0 & Diploma & Clerk of Works \\
\hline
\end{tabular}




\section{Research Question 1: Where Do You See Yourself in 5 Years' Time}

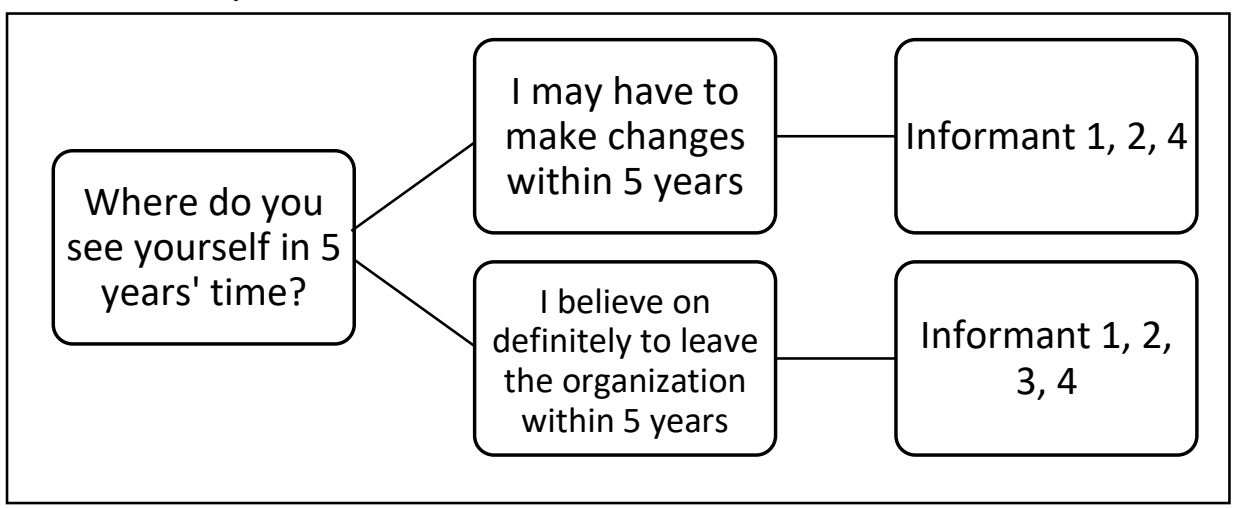

Figure 1. Where do you see yourself in 5 years' time

A question like a "where do you see yourself in 5 years' time?" was asked to obtain a holistic insight regarding work from Generation Y employees. As shown in Figure 1, most Generation $Y$ employees have plans to leave their organization or workplace for better opportunities within 5 years. Three informants believe they need the changes within 5 years on their organization or career, one of the interviewees who are currently working as Site Coordinator stated that "For me, I cannot work in the same position, same work and same environment after 5 years. If within 5 years I remain in the same position which 1 hold now I cannot see my future and challenges in my career, I need to find new challenges which can give me more skill, knowledge and experience for me to have better in my career". (Informant 2, Site Coordinator)

From the interview, four informants agreed on leaving a organization for a better option is a sensible decision. Findings from the interview revealed that the threshold for tolerance among Generation Y employees seems to be lower, and if the perceived that their work values were not being met, they will opt for better opportunities by leaving the organisation (Kim et al., 2009). Out of the five informants, none of them have plan to have their career-life permanently cemented with the same organisation. This finding supported that globally, organisation agree that it is difficult to have employees form Generation $Y$ to stay with an organisation as people from this generation tend to change jobs (Yusoff et al., 2013).

Research Question 1 aims to using empirical evidence to support the anecdotal information regarding the reason why Generation $Y$ employees decide to leave an organization in the context of Malaysia. From the interview and with the support of literature, it explains that the high turnover phenomenon experience by various industries was influenced by employees of Generation Y workforce (Sujansky \& Ferri-Reed, 2009; Yusoff et al., 2013). From the interview question, the focused emphasized on investigating work tenure in 5 years times as following human resource practitioners from Malaysia, Generation $Y$ employees were found to change job regularly and the typical duration millennial employee remain with an origination was around 18 months, compared to around 3 years for employees for prior (Sheahan, 2008). Thus, it is true that Generation $Y$ employee intent to leave their organization within 5 years.

\section{Research Question 2: What Factors Make You Leave the Organization}

A crucial question such as "what factors make them leave the organization?" and "why they choose to move to other organization?" were questioned to understand the holistic view of factors that lead to turnover intention. 


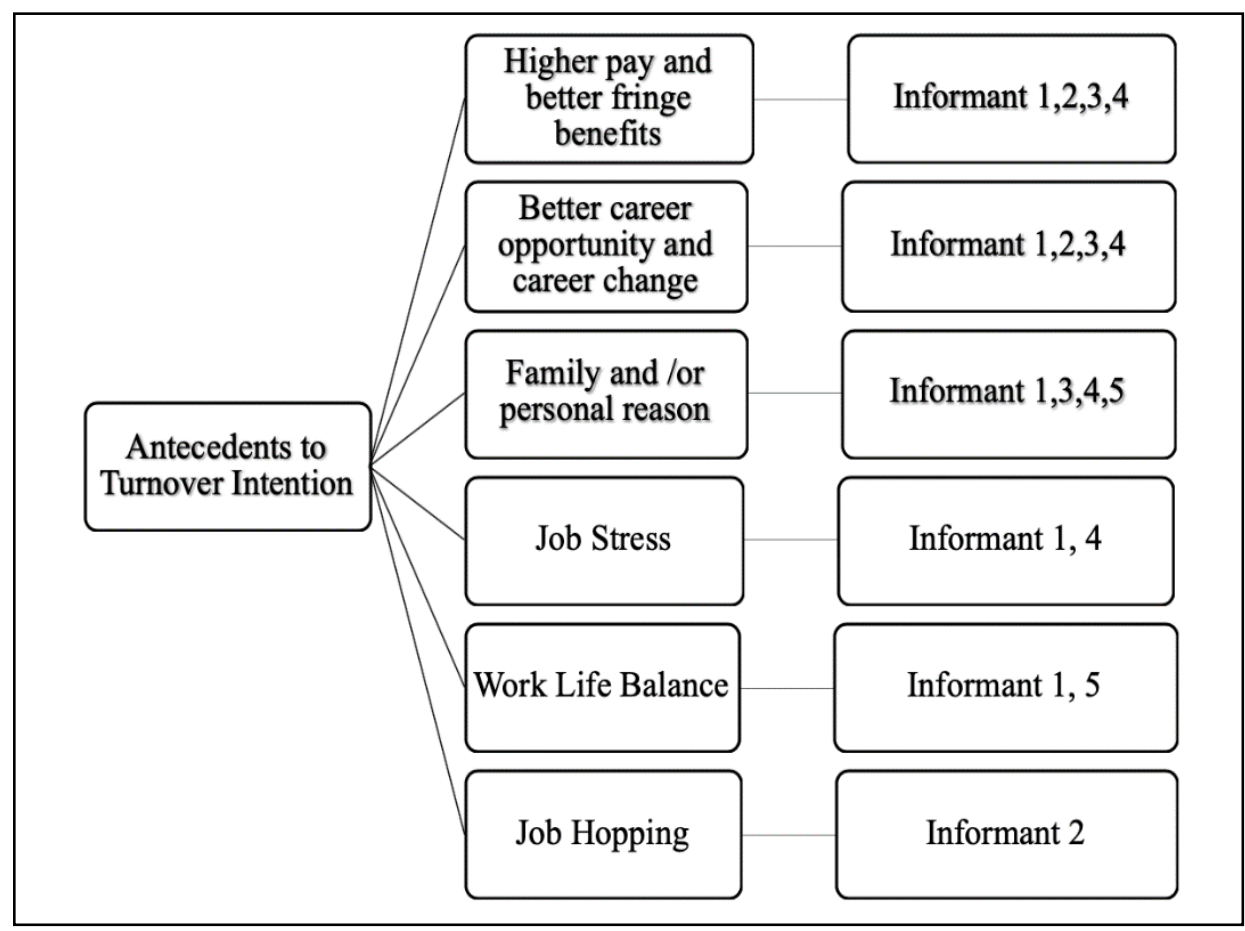

Figure 2. Where do you see yourself in 5 years' time?

Figure 2 summarize factor or antecedent why Generation $Y$ employees leave their organization. From the summary, it revealed that out of five informants, four of them highlight that they leave their organization due to get higher pay and to get better fringe benefits. They also leave the organization to find better career opportunities.

One of the informants in construction manager position clearly stated, "I had experienced in construction work and if this organization was not providing me salary and benefits which fit with my position, I do not mind finding other outside offer which willing to offer more fit with my current copetencies and experience as Construction Manager". (Informant 1, Manager Construction)

Four of informants also agreed that the intention to leave the organization is due to family or personal reason. One of the interviewees who is currently working as Clerk of Work stated that "I resigned because I need to follow my husband who is transferred to Lawas and my hometown also Lawas. I have no choice but to leave even though I happy with what I'm doing now in this organization". (Informant 5, Clerk of Work)

From the interview, it shows that due to some circumstances, someone leaves their organization voluntary due to family and other personal reason which more important for them even though it was a hard decision for them to leave their organization. Work-family conflict occurs when incompatibility occurs between the domain of work and family (Hammer et al., 2004). Work-family conflict is one of the positive influencers towards employee's' turnover (Ghayyur \& Jamal, 2013). Meanwhile, two out from five informants were mentioned that job stress and the need to improve their work-life balance as a reason why they leave the organization and move to another organization. While only one of informant stated that he leaves the organization due to job-hopping.

Figure 2 conclude that most of Generation $Y$ mostly like to take risk of making changes to their work and for them leaving a organization for a better offer or benefits is the option that most of them to take for their life. From figure 2 above, $80 \%$ of informants chose higher pay, better 
benefits and to find better career opportunity or career change as their factors why they leave the organization. This factor is significant with literature done by Cook (2015), Hammill (2005) and Wasserman (2007), which stated that individuals of Generation $Y$ are risk-takers, optimistic and are highly goal oriented. During the interview, informant 1 mentioned that he can work with any industry or as long the is willing to offer a better remuneration which is including better salary and good benefits for him to feel appreciated by the organisation.

\section{Research Question 3: What Factors Make You Leave the Organization}

Table 2

Preferences Generation Y employee on the job itself

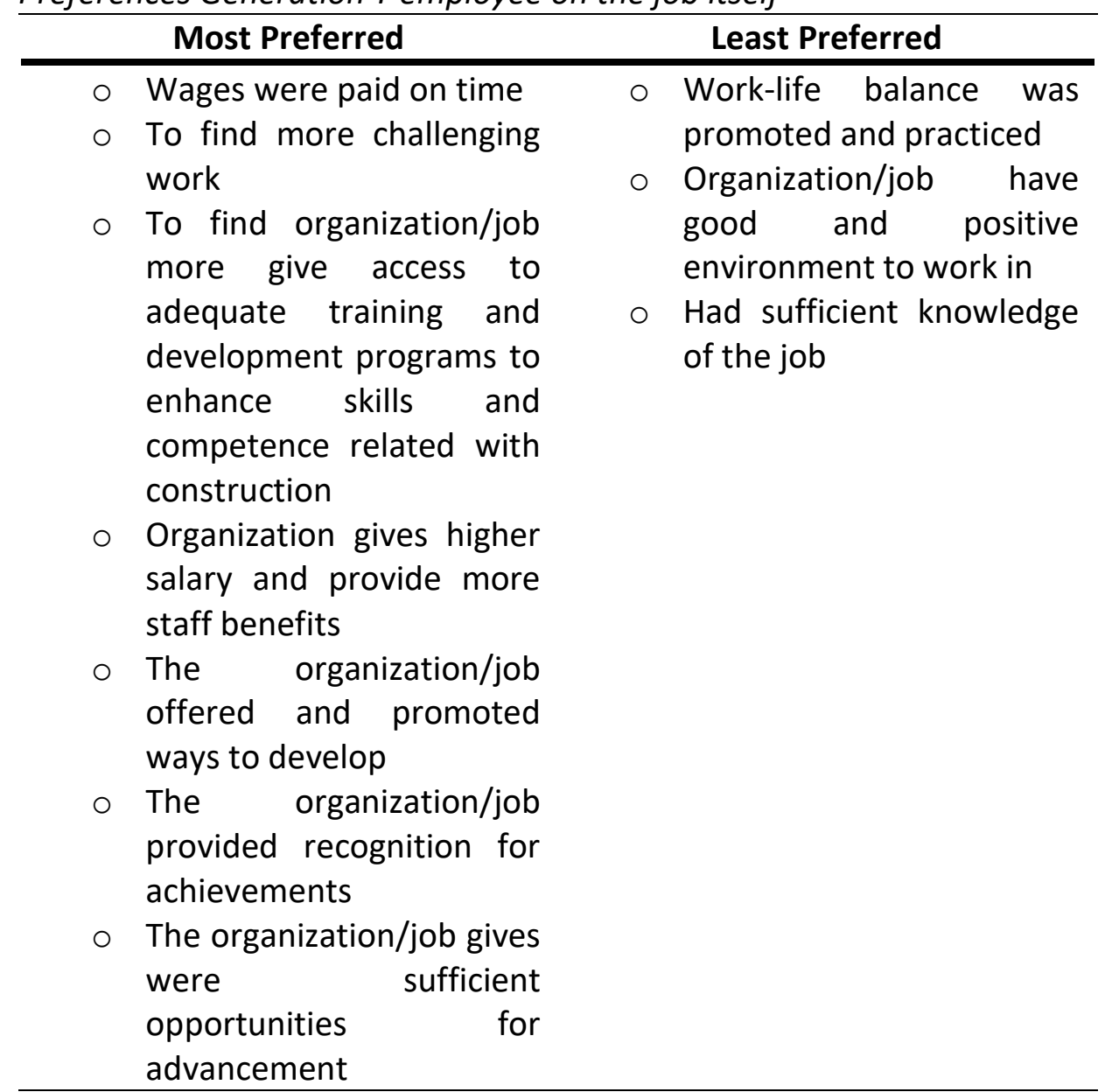

Besides, $80 \%$ of informants also choose family and/or personal reason as their important factor why they leave the organization. Generation $Y$ seeks to achieve work-life balance and their expectation towards their work seems to be different when compared to those of prior generation (Kerslake, 2005). Generation $Y$ deems work-life balance as an essential and necessary element in their lives (O'Malley, 2006), they consider maintaining a good relationship between friends and family as something important and are more intended to make their career to fit their family and personal life (Spiro, 2006).

Table 2 encapsulates that Generation $Y$ employees were more concern on their satisfaction on the job they handle or the organization they work with which can provide more training for them to enhance their skills and competencies in construction, gives good salary based on their job function and responsibility, was offered good career path and gives more recognition, promotion and advancement on their career. One of the interviewees who are currently working as Manager Construction stated that "I' $m$ happy with what I currently do 
now with my new organization. They provide me opportunities to growth in Manager Level and frequently send me for training which related with my work scope now". (Informant 1, Manager Construction)

Generation $Y$ thinks more on their achievement for their future rather than only loyal with one organization or job which cannot make them move forward on their career and future. From this result, it shows that current situation at Malaysia particularly true a study by Lee et al. (2012) concurs that employee of Generation $Y$ focuses more on salary and fringe benefits (extrinsic rewards). Table 2 revealed that employees from Generation $Y$ are willing to perform challenging work and for them as long their work was recognized. This result significant with literature from Kim et al. (2009) which stated that Generation Y employees are more likely to resign from their job if they felt that the organization cannot offer them the work values, they think is essential for their well-being. This rash behaviour or resigning if requirements are not met happen because Generation $Y$ is an impatient group of people. They want to do things fast, achieve things fast, and if they do not receive what they want, they will just move on to another organisation to find and get what they want. From the interview results, it shows that Generation $Y$ least preferred work-life balance practices in their job itself. Work-life balance here focused on where Generation $Y$ employees emphasize on organization to provide them with work autonomy (Eisner, 2005). Similarly, Twenge (2010) and Smola and Sutton (2002) revealed trend towards freedom - related work values include, but are not limited to, independence from supervision, autonomy and balance between life and work.

Generation $\mathrm{Y}$ employee intent to leave the organization when the job itself cannot give them satisfaction and the organization does not recognize their effort by the promise on promotion, not recognize their work by rewarding them or recognition (i.e., bonus or yearly salary increment). One of the characteristics of Generation $Y$ is a high expectation of personal and financial success, if the work or organization is not up to what they expect on what they do, they will move over to other organization which can give them that expectation.

As known that Generation $Y$ likes to seek challenging and do meaningful work that will impact impacts on their career and the future. If the job itself does not challenge them, it is easy for them to feel bored to do the same routine and at the end, they will move to find or try another career which more interesting and give more challenging. They do not care if they need to learn new thing which they never know or expertise before as long they have the change to explore, learn and do something which can make them satisfied and of course will give more reward to them such as high salary with better remuneration and better recognition. Characteristics of Generation $Y$ employees which more interest with something that offered them extrinsic rewards or fulfilled their needed, this notion resembles the theory of values fulfilment by Locke (1976).

\section{Implications}

This study emphasizes that the tendency of generation $Y$ employees to switch jobs after 5 years tenure with an organization due to dissatisfaction of wage and fringe benefits from the organization, to acquire better career opportunities or to change their career. Thus, employers should realize antecedents of the turnover intention among Generation $Y$ employees as they are important generation in Malaysia workforce (PwC, 2012). Providing meaningful and challenging job, coupled with proper training and career development, as well as paying compatible salary and bonuses are some strategies to retain and motivate this Generation $\mathrm{Y}$ employees, in a developing economy. 


\section{Conclusions}

In sum, Generation Y employees in the construction industry in Sarawak, Malaysia ,that involved in this study, prefer to stay at their current organization at least for five (5) years. The pull factors for turnover intention are higher pay and better benefits, better career opportunity as well as family and personal reasons. Similar to past Western literature, Gen Y in this study, will quit if they felt that the organization fail to offer challenging and meaningful job, which in line with the values fulfilment theory by Locke (1976). It is likely that the resilient growth of the Sarawak economy and development, has created the Generation Y perception that, there have many job opportunities in the market. However, different from Western literature, this Malaysian employees place high priority for salary, instead of work life balance issue, as the main reason for hopping for another job. The reason is understood as Malaysia is still developing and money is still the best motivator to retain employees.

Understanding the contributing factors on the turnover intention among Generation $\mathrm{Y}$, will enable organizations to provide an appropriate policy to retain the millennials. Proper human resource development policies, such as providing salary comparable with, or higher than market rate, training in particular enable the employees to be committed while build long term relationship with the employer (Kasa et al., 2021) and career development, can be some of the strategies to retain Gen $\mathrm{Y}$ in this construction industry.

\section{References}

Queiri, A. W. F. (2015), Explaning Generation -Y Employees' Turnover in Malaysian Context, Asian Social Science Vol. 11 No. 10. 126 - 138

Ahmad, B., Shahid, M., Huma, Z.-E.-, \& Haider, S. (2012). Turnover intention: An HRM issue in textile sector. Interdisciplinary Journal of Contemporary Research in Business, 3(12), 125.

Allen, P. (2004). Welcoming Y. Benefits Canada. 28. 51-53

Barron, P. E., Maxwell, G. A., Broadbridge, A. M., \& Ogden, S. M. (2007). Careers in hospitality management: Generation Y's experiences and perception. Journal of Hospitality and Tourism Management, 14(2), 119-128.

Black, A. (2010). Gen Y: Who they are and how they learn. Educational Horizons, 88(2), 92101.

Boles, J., Madupalli, R., Rutherford, B., \& Wood, A. J. (2007). The relationship of facets of salesperson job satisfaction with affective organizational commitment. Journal of Business \& Industrial Marketing, 22(5), 311-321. https://doi.org/10.1108/08858620710773440

Choi, S. L., Azami, A., Tan, O. K., \& Goh, C. F. (2016). An analysis on the relationship between work family conflict and turnover intention: A case study in a manufacturing company in Malaysia. International Business Management2, 10(3), 176-182. https://doi.org/10.36478/ibm.2016.176.182

Choi, S. L., Perumal, P., \& Ajagbe, M. A. (2012). The impact of human resource management practices on employees' turnover intention: A conceptual model. Interdisciplinary Journal of Contemporary Research in Business, 4(2).

Congressional Research Service. (2008). The federal workforce: Characteristics and trends. https://www.everycrsreport.com/files/20110419_RL34685_0813d4823d087da7d7cf1 5ba64c02d490e8b2d70.pdf

Cook, V. S. (2015). Engaging Generation Z students. https://sites.google.com/a/uis.edu/colrs_cook/home/engaging-generation-z-students 
Downe, A. G., Loke, S. P., Ho, J. S. Y., \& Adegbite, T. A. (2012). Corporate talent needs and availability in Malaysian service industry. International Journal of Business and Management, 7(2). https://doi.org/10.5539/ijbm.v7n2p224

Eisner, S. P. (2005). Managing Generation Y. S.A.M. Advanced Management Journal, 70(4), 4-15.

Firth, L., Mellor, D. J., Moore, K. A., \& Loquet, C. (2004). How can managers reduce employee intention to quit? Journal of Managerial Psychology, 19(2), 170-187. https://doi.org/10.1108/02683940410526127

Ghayyur, M., \& Jamal, W. (2013). Work-family conflicts: A case of employees' turnover intention. International Journal of Social Science and Humanity, 2(3), 168-174. https://doi.org/10.7763/IJSSH.2012.V2.90

Guillot-Soulez, C., \& Soulez, S. (2014). On the heterogeneity of Generation Y job preferences. Employee Relations, 36(4), 319-332. https://doi.org/10.1108/ER-07-2013-0073

Gursoy, D., Maier, T. A., \& Chi, C. G. (2008). Generational differences: An examination of work values and generational gaps in the hospitality workforce. International Journal of Hospitality Management, 27(3), 448-458. https://doi.org/10.1016/j.ijhm.2007.11.002

Hammer, T. H., Saksvik, P. Ø., Nytrø, K., Torvatn, H., \& Bayazit, M. (2004). Expanding the psychosocial work environment: Workplace norms and work-family conflict as correlates of stress and health. Journal of Occupational Health Psychology, 9(1), 83-97. https://doi.org/10.1037/1076-8998.9.1.83

Hammill, G. (2005). Mixing and managing four generations of employees. Fairleigh Dickinson University- FDU Magazine.

Hofstede, G., Hofstede, G. J., \& Minkov, M. (2005). Cultures and Organizations: Software of the Mind. 2nd Ed., McGraw-Hill.

Hom, P. W., \& Griffeth, R. W. (1991). Structural equations modeling test of a turnover theory: Cross-sectional and longitudinal analyses. Journal of Applied Psychology, 76(3), 350366. https://doi.org/10.1037/0021-9010.76.3.350

James, J. B. S., \& Walker, S. (2008). Generation Y: Comparison between Asia and the rest of the world. http://talentsmoothie.com/sbd/wp-content/uploads/2012/07/Asia-GenYReport.pdf

Juhdi, N., Pa'wan, F., \& Hansaram, R. M. K. (2013). HR practices and turnover intention: The mediating roles of organizational commitment and organizational engagement in a selected region in Malaysia. The International Journal of Human Resource Management, 24(15), 3002-3019. https://doi.org/10.1080/09585192.2013.763841

Karefalk, A., Petterson, M., \& Zhu, Y. (2007). How to motivate Generation Y with different cultural backgrounds- A cross-cultural comparison between China and Sweden. Kristianstad University.

Kasa, M., Leong, Choi-Meng, Leong, Pudun, J., Poh, S. \& Ramli, N. (2021). The Relationship of Human Resource Practices (HRP) Constructs With Turnover Intention Among Employees in Sarawak, Malaysia. Research in World Economy, 12(1), 43-55. https://doi.org/10.5430/rwe.v12n1p43

Kerslake, P. (2005), Words from the Y's. New Zealand Management, 52, 44-46.

Kim, H., Knight, D. K., \& Crutsinger, C. (2009). Generation Y employees' retail work experience: The mediating effect of job characteristics. Journal of Business Research, 62(5), 548-556. https://doi.org/10.1016/j.jbusres.2008.06.014

Kultalahti, S., \& Viitala, R. (2015). Generation Y - challenging clients for HRM? Journal of Managerial Psychology, 30(1), 101-114. https://doi.org/10.1108/JMP-08-2014-0230 
Kupperschmidt, B. R. (2000). Multigeneration employees: Strategies for effective management. The Health Care Manager, 19(1), 65-76. https://doi.org/10.1097/00126450-200019010-00011

Lee, C. S., Hung, D. K. M., \& Ling, T. C. (2012). Work values of Generation Y preservice teachers in Malaysia. Procedia - Social and Behavioral Sciences, 65, 704-710. https://doi.org/10.1016/j.sbspro.2012.11.187

Locke, E. A. (1976). The nature and causes of job satisfaction. In Handbook of Industrial and Organizational Psychology (pp. 1297-1343). Randy McNally \& Co.

Loughlin, C., \& Barling, J. (2001). Young workers' work values, attitudes, and behaviours. Journal of Occupational and Organizational Psychology, 74(4), 543-558. https://doi.org/10.1348/096317901167514

Marc, A. P. (2018). High Employee Turnover as a Silent Construction Manpower Crisis. https://rensol.com/employee-turnover-construction-industry/

Martin, C. A. (2005). From high maintenance to high productivity. Industrial and Commercial Training, 37(1), 39-44. https://doi.org/10.1108/00197850510699965

Martin, C. A., \& Tulgan, B. (2006). Managing the generation mix: From urgency to opportunity (2nd ed.). MA: HRD Press.

Mbah, S. E., \& Ikemefuna, C. O. (2012). Job satisfaction and employees' turnover intentions in total Nigeria plc. in Lagos state. International Journal of Humanities and Social Science, 2(14).

Meier, J., \& Crocker, M. (2010). Generation Y in the workforce: Managerial challenges. The Journal of Human Resource and Adult Learning, 6(1).

O'Malley, S. (2006). Attracting and retaining Generation $Y$ employees. Insurance Advocate, $117(24), 27$.

Kementerian Kerja Raya Malaysia. (2011) Persidangan Pegawai Kanan KKR dan Agensi (2011). The Key Issues in the Malaysian Construction Industry: Public and Private Sector Engagement. https://www.kkr.gov.my/files/MBAM.pdf

PwC. (2012). Millennials at work: Reshaping the workforce. https://www.pwc.com/my/en/assets/publications/millennials-at-work.pdf/

Queiri, A., Yusoff, W. F. W., \& Dwaikat, N. (2015). Explaining Generation-Y employees' turnover in Malaysian context. Asian Social Science, 11(10), 13. https://doi.org/10.5539/ass.v11n10p126

Samad, S. (2006). The contribution of demographic variables: Job characteristics and job satisfaction on turnover intentions. Journal of International Management Studies, 1(1).

Schyns, B., Torka, N., \& Gössling, T. (2007). Turnover intention and preparedness for change. Career Development International, 12(7), 660-679. https://doi.org/10.1108/13620430710834413

Shabanesfahani, A., \& Tabrizi, M. R. F. (2012). Barriers of systemtic innovation to increase productivity of engineering and construction industries of the world. IOSR Journal of Mechanical and Civil Engineering, 4(1), 43-50.

Sheahan, P. (2008). Generation-Y in Asia. The University of Sydney.

Smola, K. W., \& Sutton, C. D. (2002). Generational differences: Revisiting generational work values for the new millennium. Journal of Organizational Behavior, 23(4), 363-382. https://doi.org/10.1002/job.147

Spiro, C. (2006). Generation $Y$ in the workplace. http://www.dau.mil/pubs/dam/11_12_2006/11_12_2006_spi_nd06.pdf

Sujansky, J., \& Ferri-Reed, J. (2009). Keeping the millennials: Why companies are losing 
billions in turnover to this generation-and what to do about it (1st ed.). Wiley.

Tapscott, D. (2009). Grown up digital: How the net generation is changing your world. McGraw-Hill.

Tett, R. P., \& Meyer, J. P. (1993). Job satisfaction, organizational commitment, turnover intention, and turnover: Path analyses based on meta-analytic findings. Personnel Psychology, 46(2), 259-293. https://doi.org/10.1111/j.1744-6570.1993.tb00874.x

Twenge, J. M. (2010). A Review of the empirical evidence on generational differences in work attitudes. Journal of Business and Psychology, 25(2), 201-210. https://doi.org/10.1007/s10869-010-9165-6

Twenge, J. M., \& Campbell, S. M. (2008). Generational differences in psychological traits and their impact on the workplace. Journal of Managerial Psychology, 23(8), 862-877. https://doi.org/10.1108/02683940810904367

Wasserman, I. (2007). Generations working together. https://www.entrepreneur.com/article/183720

Yusoff, W. F. W., Queiri, A., Zakaria, S., \& Hisham, R. R. I. R. (2013). Generation-Y turnover intention in business process outsourcing sector. In 2nd International Conferences on Management, Economics and Finance (2nd ICMEF 2013) Proceeding. Kota Kinabalu: ICMEF.

Zulbahari, N. H., \& Alias, R. (2014). Malaysia's trend of employment turnover: Study on Generation Y. Journal of Modern Marketing Research, 3(1), 01-13. 